\title{
The Fiction of Development: \\ Literary Representation as a Source of Authoritative Knowledge
}

David Lewis $^{1}$, Dennis Rodgers ${ }^{2}$ and Michael Woolcock $^{3}$

January 2008

d.lewis@lse.ac.uk

dennis.rodgers@manchester.ac.uk

michael.woolcock@manchester.ac.uk

${ }^{1}$ London School of Economics

2,3 Brooks World Poverty Institute University of Manchester

Brooks World Poverty Institute ISBN : 978-1-906518-19-6

\section{BWPI Working Paper 20}

Creating and sharing knowledge to help end poverty 


\begin{abstract}
This article introduces and explores issues regarding the question of what constitute valid forms of development knowledge, focusing in particular on the relationship between fictional writing on development and more formal academic and policy-oriented representations about development issues. We challenge certain conventional notions about the nature of knowledge, narrative authority, and representational form, and explore these by comparing and contrasting selected works of recent literary fiction that touch on development issues with academic and policyrelated representations of the development process, thereby demonstrating the value of taking literary perspectives on development seriously. Not only are certain works of fiction "better" than academic or policy research in representing central issues relating to development, but they also frequently reach a wider audience and are therefore more influential. Moreover, the line between fact and fiction is a very fine one. The article also provides a list of relevant works of fiction that we hope academics and practitioners will find both useful and enjoyable.
\end{abstract}

Key words: development knowledge, representation, narrative authority, fiction

David Lewis is Reader in Social Policy in the Department of Social Policy at the London School of Economics.

Dennis Rodgers is Senior Research Fellow at the Brooks World Poverty Institute at the University of Manchester.

Michael Woolcock is Research Director of the Brooks World Poverty Institute and Professor of Social Science and Development Policy at the University of Manchester.

\title{
Acknowledgements
}

For helpful discussions and comments we are grateful to two anonymous referees, Xavier de Souza Briggs, Paola Grenier, Scott Guggenheim, John Harriss, Craig Johnson, Naila Kabeer, Jenny Kuper, Vijayendra Rao, Sue Redgrave, Imogen Wall, and the 2002-03 and 2003-04 LSE Development Studies Institute MSc student cohorts. The usual disclaimers apply.

The views expressed in this paper are those of the authors alone, and not necessarily those of the respective institutions with which they are affiliated.

Please address all comments and questions to dennis.rodgers@manchester.ac.uk,

d.lewis@lse.ac.uk, and michael.woolcock@manchester.ac.uk

Forthcoming in Journal of Development Studies, Vol. 44, No. 2 (February) 2008 
But words are things, and a small drop of ink,

Falling like dew upon a thought, produces

That which makes thousands, perhaps millions, think. ${ }^{1}$

My task which I am trying to achieve is, by the power of the written word, to make you hear, to make you feel - it is, above all, to make you see. That - and no more, and it is everything."

\section{Introduction: development and representation}

"Development" is one of the key organising concepts of the modern era. As such, ideas and images of development are inevitably represented in a wide variety of ways, whether within academia, the policy world, or the general public domain. To this extent, it can be contended that all forms of development knowledge can be - and historically have been - largely understood as a series of "stories". This is true not only in the pragmatic sense that to have an impact on public opinion, organisational strategy, or within academia, even the most elaborate equations and sophisticated data analyses need to be able to be expressed in everyday language (Denning, 2000), but also in the deeper philosophical sense that all knowledge claims are necessarily embedded in particular subjective understandings of how the world works, as was famously pointed out by Walter Benjamin (1989) in his classic essay "On the Program of the Coming Philosophy".

Benjamin not only contended that all knowledge of reality is unavoidably subjective but also that it is inevitably mediated by the representative forms which describe it, and that different modes of representation therefore impart different visions of the world. He was of course not the first to highlight this issue, which can be placed within a philosophical tradition going back in the West to the 4th century BC and Plato's famous "Simile of the Cave", and even further in the East, to the 6th century BC parable of the blind men and the elephant recorded in the Buddhist Udana. We take Benjamin (1989: 9-10) as our starting point, however, because he saw this concern as critical for the social sciences, arguing that the key challenge was the creation of "a concept of knowledge to which a concept of experience corresponds". Benjamin made it his life's work to design a form of representation which would capture the subjective dimension of social reality whilst simultaneously allowing an objective knowledge of the world. ${ }^{3}$ Our purpose in this article is more modest; we seek merely to suggest that there may be a case for widening the scope of the development knowledge base conventionally considered to be "valid". In doing so, we aim to open up new ground within development studies for the further exploration of the value of different forms of development knowledge, and to this extent we acknowledge that our paper inevitably seeks more to ask questions than to provide answers.

\footnotetext{
${ }^{1}$ Byron, (1973 [1819-24]: 182).

2 Conrad (1985 [1897]: 1).

${ }^{3}$ This culminated in Benjamin's celebrated Arcades Project, an unfinished palimpsest of assorted notes, quotations, and aphorisms which attempted to put together a new theory of history embodied in a new literary and philosophical historiography (see Benjamin, 1999).
} 
Our central contention concerns the potential contribution that works of literary fiction can make to development. ${ }^{4}$ It is important to note from the outset that our intention is not to make any relativist epistemological claims that literary forms of representation can substitute for academic or policy works in the study of development. Rather, we want to lay down a challenge to practitioners and academics within the field to include fictional representations of development issues within the scope of what they consider to be "proper" forms of development knowledge. The article begins by making some general remarks about the nature of knowledge, narrative authority, and representational form, highlighting in particular the common ground that exists between fiction and non-fiction. We then explore the contributions that a number of works of modern popular fiction touching on development themes potentially make to our understanding of development, and juxtapose these with the contributions of more formal academic and applied approaches. A final section sets out an agenda for further debate, draws some preliminary conclusions and proposes a list of relevant works of fiction that we feel may be of interest to those whom we may have persuaded of the importance of our endeavour.

\section{Knowledge, authority and narrative form}

There clearly exists within development studies a hierarchy of authority which determines what constitutes "valid" development knowledge. Although much of the sound and fury in today's development debates stems from what can be described as a "clash of epistemologies" - in which different understandings of the meanings and renderings of development come into contact with one another - in many ways there exists a much deeper schism that affects the very nature of what is considered knowledge and what is not. This involves decisions about the acceptable form that development "stories" must take to be deemed serious. Even if in recent years there have been some attempts to broaden the development knowledge base beyond traditional academic monographs and policy manuals - including perhaps most notably the World Bank's "Voices of the Poor" initiative, ${ }^{5}$ which has explicitly sought to bring a story-telling methodology centre-stage within the production of development knowledge - these remain overwhelmingly the standard representational form for the dissemination of development knowledge within the discipline. As such, they can be said to constitute the benchmark against which other forms of knowledge representation are measured within development studies - broadly construed as encompassing both the academic and practitioner worlds - and those that do not match up are generally discarded or ignored, including in particular literary forms of representation.

To a certain extent, this devaluing of narrative forms of knowledge mirrors a fundamental divide between literature and social science. As Barbara Czarniawska-Joerges (1992: 218) succinctly outlines - and simultaneously undermines - the separation derives from at least three factors:

\footnotetext{
${ }^{4}$ In this paper we are limiting ourselves to works of literary fiction due to limitations of space, but we fully recognise that other forms of fictional representation, such as films and plays, constitute important communicative mediums for addressing key themes in development. In the future we hope to write a separate paper on "development" as addressed in films (tentatively titled "The projection of development").

${ }^{5}$ See Narayan et al. (2000a \& 2000b), and Narayan and Petesch (2002). See also the "Voices of the Poor" website at: http://www.worldbank.org/poverty/voices/
} 
The first is that one is fiction and the other is non-fiction: the basis for telling the story is different. However, this is relative. There are many writers who use factual events for their novels and many social scientists who use fictitious reality to illustrate their theses... The second is that social scientists are obliged to be systematic, that is, to demonstrate a method, which is also relative. Writers often have a very systematic method... The third is the presence or lack of aesthetic expression, and this is a difference that, following R.H Brown ... I propose to abolish.

The historian Hayden White (1973) implicitly goes even further in dismissing this distinction in his famous study of the "historical imagination" when he contends that social science often tends to draw its authority from its perceived aesthetic value rather than the use of putatively "factual" data or "objective" theory. Focusing on nineteenth century European historical accounts, he shows how these were structured along similar lines to the realist novel, with their force and persuasion deriving principally from the deployment of similar rhetorical strategies to those found in the latter. According to White, this was because ultimately all interpretation is fundamentally rhetorical in nature; it is a process that occurs when there is uncertainty as to how to describe or explain a phenomenon, and consequently figurative rather than objective means of persuasion will inevitably be resorted to.

Seen in this way, the line between literature and the social sciences becomes a very fine one. This is also the case when storytelling is considered historically, as one of mankind's oldest methods of possessing information and representing reality. Certainly, as Michel Foucault (1984) has perceptively pointed out, those texts that we today categorise as "literary fiction" - stories, poems, plays - were in fact once accepted as the primary media for the expression of essential truths about human dilemmas and understandings of the world, in the same way that in this day and age positivist scientific discourse is received as authoritative pro forma. Indeed, fiction is arguably to a large extent frequently about the very issues that at a basic level are the subject matter of development studies: the promises and perils of encounters between different peoples; the tragic mix of courage, desperation, humour, and deprivation characterising the lives of the downtrodden; and the complex assortment of means, motives, and opportunities surrounding efforts by outsiders to "help" them. From this perspective, one might even say - with apologies to the William Shakespeare - that in many ways stories "are such stuff as [development studies] are made on". ${ }^{6}$

Furthermore, the role of literature has historically always been not only "to delight" but also "to teach", as was pointed out by the Roman poet Horace over two thousand years ago. ${ }^{7}$ Sir Thomas More famously claimed that he was compelled to write his powerful political tract Utopia (1516) as "a fiction whereby the truth, as if smeared by honey, might a little more pleasantly slip into men's minds" (More, 1964: 251). This prescriptive ideal was perhaps most clearly expressed in late $18^{\text {th }}$ century Britain during the debates around the so-called

\footnotetext{
${ }^{6}$ See Shakespeare's The Tempest, Act IV, scene 1, line 155.

7 Horace's original expression was that literature - and more specifically poetry - should be both "sweet and useful" (see Horace, 1959: 75). Its oft-cited formulation as "to teach and to delight" is generally attributed to the $16^{\text {th }}$ century soldier-poet Sir Philip Sydney in his famous Apology for Poetry (2002 [1595]).
} 
"republic of letters" that the industrial revolution and a concomitant concentration of an increasingly literate population into urban centres were seen to be creating (see Keen, 1999). Literature was considered politically charged within the context of Britain's changing social conditions, and a powerful vector for shaping of public values and morality, to the extent that the British anarchist William Godwin (1993 [1793]: 20) wrote:

Few engines can be more powerful, and at the same time more salutary in their tendency, than literature. Without enquiring for the present into the cause of this phenomenon, it is sufficiently evident in fact, that the human mind is strongly infected with prejudice and mistake. The various opinions prevailing in different countries and among different classes of men upon the same subject, are almost innumerable... Now the effectual way for extirpating these prejudices and mistakes seems to be literature.

The power of literature to effectively convey complex ideas should not be surprising. Over forty years ago, Lewis Coser published the first edition of his classic (but unfortunately now out-of-print) Sociology through Literature, an unprecedented introduction to sociology through an eclectic collection of literary fiction. Citing Henry James in the introduction to his volume, Coser (1972 [1963]: xv) argued that "there is no impression of life, no manner of seeing it and feeling it, to which the plan of the novelist may not offer a place". As such, writers of fiction "have provided their readers with an immense variety of richly textured commentaries on man's life in society, on his involvement with his fellow-men," to the extent that literature can constitute a key form of social evidence and testimony. Coser (1972 [1963]: xvi) was careful however not to suggest that literature could replace "systematically accumulated, certified knowledge". Rather, he saw them as complementing each other, but argued that "social scientists have but too often felt it is somewhat below their dignity to show an interest in literature". This "self-denying ordinance" was highly problematic according to Coser (1972 [1963]: xvi), who contended that

there is an intensity of perception in the first-rate novelist when he describes a locale, a sequence of action, or a clash of characters which can hardly be matched by ...sociologists. ... The creative imagination of the literary artist often has achieved insights into social processes which have remained unexplored in social science.

From this perspective, an argument can clearly be made that it might be useful to compare and contrast literary views on development with the ideas and perceptions of academic social science and the public policy world, in order to glean new insights and novel perspectives (so to speak). Certainly, the themes emanating from "development policy" documents - the official texts produced by multilateral development agencies, government planning offices, and NGOs - can often be rather starkly contrasted with those of fictional writing on development. For example, in a stimulating study of the way in which the World Bank construes Egypt's development predicament, Timothy Mitchell (2002) underlines how official documents portray this as a function of demographic and geographic factors - too many people producing too little food because of not enough arable land - and how this has in turn given rise to a corresponding policy focus on agricultural and irrigation projects. 
However, literary authors such as the Nobel Prize winning Naguib Mahfouz, in his novels Adrift on the Nile (1993[1966]) and The Journey of Ibn Fattouma (1993 [1983]), or Ahdad Soueif in her Booker Prize nominated novel The Map of Love (1999), provide very different analyses, respectively pointing to factors including modernization and the concomitant spread of anomie, religious fundamentalism, and the colonial legacy as critical to explaining Egypt's contemporary predicament. The wider corpus of Mitchell's work (see 1991; 2000) strongly supports that these are key factors to understanding the country's current development.

Similarly, the recent and influential World Bank (2000) report Can Africa Claim the $21^{\text {st }}$ Century? - co-authored with several other development organisations, it should be noted is another example of such disjuncture. It optimistically and proactively affirms that Africa's future depends on "determined leadership", "good governance", "sound policies", "improved infrastructure", "investments in people", "reduced conflict", "higher economic growth", and "reduced aid dependence". While all of these factors are undoubtedly eminently sensible from an "orthodox" policy point of view, they ring like empty platitudes when held up against the insights of fictional accounts of Africa's developmental predicament such as Chinua Achebe's Things Fall Apart (1958) or J. G. Ballard's The Day of Creation (1987), for example. Achebe's novel details the lasting legacy of colonialism in Nigeria, including the conflicts generated around cultural practices, but it also traces the power struggles that traditionally run through tribal communities, showing these to also be a source of change and constant struggle. Ballard's The Day of Creation actually focuses directly on development practice insofar as the central character is a doctor - significantly named Dr. Mallory - running a WHO clinic in an unnamed underdeveloped, drought-plagued, and poverty-ridden West African country caught in the midst of a civil war. As the novel unfolds, Mallory is confronted with the perversity of the processes and manifestations that he once saw as epitomising development, ultimately drawing conclusions about the futility of the process as conceived on Western terms.

The argument that we are trying to make here is not that academic or policy approaches to development are necessarily wrong or flawed, nor is it that we think novelists should be put in charge of development ministries. Rather, our point is that the policy and academic literature of development often constructs development problems in a way that justify the response of the particular policies they advocate (Ferguson, 1990; Escobar, 1995; Mitchell, 2002), and that the way this literature is framed therefore makes a significant difference. This is of course an issue that can be said to go to the heart of the art of story-telling, ${ }^{8}$ and indeed, Emery Roe (1991 \& 1994) argues that to a large extent policy documents such as those produced by the World Bank should be understood as "narratives" that frame what and how development problems are discussed by powerful actors, thereby validating the ubiquitous role of (and interventions by) professional "experts", and legitimising efforts to construe deeply complex historical and political issues as being most effectively - and most

\footnotetext{
${ }^{8}$ Indeed, as Mark Moore (1987: 80) astutely notes, the ideas that become dominant public ones frequently do so insofar as they "distinguish heroes from villains, and those who must act from those who need not. ...[T]o the extent that these distinctions fit with the aspirations of the parties so identified, the ideas will become powerful. If powerful people are made heroes and weaker ones villains, and if work is allocated to people who want it and away from people who do not, an idea has a greater chance of becoming powerful".
} 
"rigorously" - addressed through technocratic means, for example through the adoption of "tool kits", "better policies", "best practices", and "stronger institutions" as determined by "solid evidence" and "rational planning". ${ }^{9}$ Such documents inherently privilege certain forms of information, explanation, and "evidence", ${ }^{10}$ and in conjunction with the politically powerful places from whence they emanate - and the imperatives that Weberian organisations have for presenting problems and solutions in neat packages (Pritchett and Woolcock, 2004) thereby according a particular status to certain forms of knowledge, authority, and representation. ${ }^{11}$

Obviously, as scholars-practitioners ourselves, we are acutely conscious of the constant need to frame complex development issues in ways that resonate with broad audiences students, advocacy groups, politicians, bureaucrats - and that are plausibly "actionable" by front-line project staff. This inevitably often means accepting a certain amount of "blueprint development" that "tell[s] us at once that things happen 'like' the way they are described after all narratives relate things causally - without, however, reflecting the fact that things happen ...so uncertainly" (Roe, 1991: 296). At the same time, however, another way of putting this is that having a "good story" is essential if one wants to make a difference in the world (as most people in development surely are). Seen in this way, it can plausibly be contended that works of fiction, as original bona fide "stories", also potentially have much to contribute to the storehouse of knowledge on development processes, manifestations, and responses. When one story is a more compelling means of articulating a situation than another, then development scholars and practitioners ought to perhaps think more positively about it, be it a novel, a poem, or a play rather than an academic monograph or policy report.

From this perspective, it can be contended that as the scholarly and policy communities continue to grapple in the beginning of this new millennium with ways to ameliorate their theories and strategies of development, turning to novelists, poets, and playwrights for inspiration and ideas could plausibly be instructive. The next sections endeavour to take literary perspectives on development seriously, teasing out a number of themes and lessons from selected examples in order to demonstrate to those who primarily concern themselves with more formal - empirical, theoretical, and applied - representations of development that alternative narratives may also be of potential interest. ${ }^{12}$ The authors we have selected are those that, for different and sometimes idiosyncratic reasons, we feel have important things to say, regardless of their origins, and whose work illustrates the points that we wish to make. We do not claim to be either exhaustive or representative in our choices of literary works, which are dictated by our own personal readings, and hope that our partial coverage will stimulate others to propose their own short-lists of readings.

\footnotetext{
${ }^{9}$ See also Scott (1998) for a discussion of similar processes in relation to the development of the modern state.

${ }^{10}$ The same can be said of some academic contributions - see for example Collier and Gunning (1999).

11 Indeed, on the basis of his close engagement over many years with a large development project in Western India, David Mosse (2004) in fact goes so far as to suggest that policy documents are largely ex post rationalisations of development practice, with both means and ends shifting in accordance with political fortunes and (perceived) project efficacy. At the same time, see Bebbington et al. (2004) for a response by "insiders" to the use of public documents to divine and assess World Bank "policy" in the realm of social development.

12 In some respects there are parallels between this article and Sherman (2001), who uses literary sources to document changing public attitudes toward the poor in turn of the nineteenth century Britain. See also Herman (2001) on the rendering of the poor in nineteenth-century Russian literature.
} 
Moreover, although some of the works of fiction to which we make reference have been written by writers from the developing world, it is important to note that we are not attempting to construct a case for literature being a "voice from the developing world". This is an issue that Frederic Jameson (1986) considered in a classic essay on "Third-World Literature in the Era of Multinational Capitalism", where he proposed that all third world texts be read as "national allegories". Jameson was subsequently widely accused of being patronising and Eurocentric (see for example Ahmad, 1987), although Imre Szeman (2001: 804) has recently suggested that "almost without exception, critics of Jameson's essay have wilfully misread it", thereby obscuring "a sophisticated attempt to make sense of the relationship of literature to politics in the decolonizing world". Although this latter issue is clearly relevant to our task at hand, our canvas is much narrower than that of Edward Said (1993: xiii), for example, who explores the world of narrative fiction in terms of its position "in the history and world of empire". ${ }^{13}$ Along with Said, we very much recognise the fact that "the power to narrate, or to block other narratives from forming and emerging, is very important to culture and imperialism, and constitutes one of the main connections between them", but our focus is on literature in general as an alternative representational genre through which to understand development processes and phenomena.

\section{The usefulness of literary perspectives on development}

In her recent study of non-governmental organisation (NGO) issues in the Philippines, Thea Hilhorst (2003) begins by making a strikingly unfavourable comparison between mainstream academic writing on NGOs and the portrayal of the world of NGOs in a recent work of popular fiction. Hilhorst opens her monograph with a brief discussion of Helen Fielding's novel Cause Celeb (1994), a mainly light-hearted chronicle of the adventures of Rosie, a disenchanted London public relations manager who becomes involved in international humanitarian efforts to address famine in an African country. ${ }^{14}$ Hilhorst's (2003: 1-2) point is that, perhaps unexpectedly, Fielding's novel presents a relatively nuanced picture of international development work and organisational life:

In the novel, Rosie's NGO does what organisations do: it has a mission and clear objectives, staff with differentiated responsibilities, and it works with a budget for planned activities. Yet the novel also brings out how this NGO is shaped by actors in the organisation and their surrounding networks. These people carry out activities according to their understanding of the situation and follow the whims of their personalities, motivated by various combinations of sacrifice, self-interest, vanity and

\footnotetext{
${ }^{13}$ This is an issue that has been extensively taken up within the emergent field of "cultural studies", as part of its effort to achieve a synthesis of social science and literary studies. In particular, it aims to "dismantle the elitism of the distinction between high and popular culture within literary studies" (Schech and Haggis, 2000: 26), which in many ways we see as analogous to our interest in questioning the distinctions between different types of knowledge about development. Cultural studies as a discipline is however much broader and also concerned with the relationship between society and the production of texts, which is an issue that it is beyond the scope of this paper to explore in detail, although obviously relevant.

${ }^{14}$ Changing emphasis to a completely different subject matter, Fielding later went on to write the hugely popular and influential Bridget Jones "chick-lit" novels.
} 
compassion. It also places the humanitarian activities in their political context, both in the local situation of a country at war and in the politics of development bureaucracies and fundraising. Finally, the novel delightfully turns the refugees into real people-good and bad, loveable and pitifulwho actively endeavour to enrol NGO staff members and visitors to provide the necessary assistance.

Fielding's novel is strikingly different from most of the scholarly literature on NGOs. Reading this literature, one is usually presented with a black-andwhite picture in which managers play the lead roles, all other actors remain silent and the organisations unfold their objectives in a participatory way. One wonders what these tidy organisations have to do with the other realities that reach us from developing countries, including social and political movements, conflict and fundamentalism. And one keeps wondering what really happens inside the organisations and how this relates to the lives of the NGO staff, volunteers and beneficiaries.

Hilhorst goes on to ask the question of "why would Helen Fielding succeed in giving this reallife account of an NGO where development scholars have failed, apart from the obvious reason that she brings her literary talent to this task?" The answer, she contends, is that development research on organisations in general and on NGOs in particular has paid too much attention to the formal organisational world and has assumed its boundaries, thereby ignoring the stories of the people who work in and with these organisations as well as the formal and informal relationships which link everyday practices across formal organisational boundaries. The nuanced portrayal of the NGO world in Fielding's novel contrasts strongly with this lack of imagination and depth, and illustrates well the point that informs our argument in this article, namely that fictional accounts of development can sometimes reveal different sides to the experience of development and may sometimes even do a "better" job of conveying the complexities of development than research-based accounts. ${ }^{15}$

Akhil Gupta (2005) similarly demonstrates the power of fiction in a recent article where he draws on both academic and literary works in order to write about corruption in India, including in particular, the novel Raag Darbari by Shrilal Shukla (1992 [1968]). According to Gupta (2005: 20-21), this latter narrative is not only "one of the richest works of fiction about the postcolonial Indian state" but arguably "a work whose insights into politics and the state in rural India are without comparison". Indeed, Gupta goes on to claim that "it is hard for me to think of another novel or ethnography that gives a more clearly etched picture of the large villages and small tehsil towns". At the same time, however, it can be argued that Gupta (2005: 21) effectively treats Raag Darbari as quasi-formal ethnographic research when he claims that its sharp portrayal of social reality derives from the fact that Shukla

\footnotetext{
${ }^{15}$ Many other scholars and practitioners have made similar use of literature to highlight an issue, although few explicit their logic for doing so as clearly as Hilhorst. Von Struensee (2004), for example, uses Nigerian writer Buchi Emecheta's novel The Bride Price (1976) as a means of introducing the subject of bride price in a recent overview paper on the domestic relations bill in Uganda. In a related manner, it is common for social scientists to preface their work with literary citations, implicitly because they are revealing of the issue being written about (and no doubt also because this tends to generate a certain aura of cultural sophistication).
} 
served in the U.P. state provincial service, and then the Indian Administrative Service, being posted mainly around Lucknow. He could thus draw upon a lifetime of experience and observation in those settings that form the stage for the novel.

While this may well be the case, much of the force of the book clearly also derives from its literary qualities as a novel. Raag Darbari won one of India's most prestigious literary awards - the Sahitya Akademi Award - in 1970, and is widely considered to have taken the satirical genre to new heights within the context of Hindi-language post-Independence literature. The novel is a picaresque comedy that draws readers in through a series of inter-linked stories that are in turn satirical, ironic, and tragic, making witty use of vernacular wordplay and caricature, and providing rich, fine-grained descriptions of post-Independence rural smalltown India. It furthermore ends on an unambiguous and in many ways prophetic message about the venality of local politics and the vice-like nature of poverty in the countryside that did much to change dominant perceptions of rural India at the time. In particular, the dramatic finale that suggests that migration is the only hope for the rural poor radically challenged prevalent romantic stereotypes of the Indian countryside being idyllic, harmonious, and timeless in a way that many academic and policy texts on rural India pointedly failed to do during the 1950s and 1960s. As such, Raag Darbari arguably constitutes an example of literary fiction that can be considered "better" - albeit in hindsight - than much of the academic or policy-oriented research from this period as a result of its nuanced understanding and detailed depiction of key development issues.

One reason for Raag Darbari's successful depiction of the nature of rural poverty in India is arguably also the fact that it was not written within the restrictive conventions of academic or policy writing. Beyond superficial issues, such as the need for proper referencing, paying one's dues to predecessors, and so on, fictional writing can be said to enjoy a freedom of fabrication that allows it to present "ideal type" exemplifications of social phenomena in a way that empirically grounded academic literature sometimes cannot. The advantages are especially clear in relation to Rohinton Mistry's Booker-prize nominated novel, A Fine Balance (1996), which is all the more germane to this discussion insofar as Mistry explicitly writes with the intention to do more than simply entertain, prefacing his work with a quotation from Balzac's Le Père Goriot that deliberately seeks to blur the boundary between "truth" and "fiction":

Holding this book in your hand, sinking back in your soft armchair, you will say to yourself: perhaps it will not amuse me. And after you have read this story of great misfortunes you will no doubt dine well, blaming the author for your own insensitivity, accusing him of wild exaggeration and flights of fancy. But rest assured: this tragedy is not a fiction. All is true.

A Fine Balance is set primarily at the time of the 1975-77 State of Internal Emergency in India, and traces the fortunes of four fictional characters as they try to survive communal tensions, rural to urban migration, downward socio-economic mobility, the state violence of population control programs, and the fragile search for mutual support networks, productive activity, employment and informal social services in Bombay. It is a relentlessly downbeat 
novel that concerns itself with almost unbearable hardship and tragedy, but Mistry manages to entertain through the deployment of a style that borders on the ethnographic - a representational method that has only rarely been evident within the development studies mainstream - that invokes the essential "being there" quality that convinces a reader over and above "either a factual look or an air of conceptual elegance" (Geertz 1988: 4). The book is particularly carried by the powerfully-drawn characters inhabiting this vividly described world, and A Fine Balance clearly has an edge over academic or policy texts as a result, as demonstrated by the fact that the novel has as become a fixture on university reading lists for courses on subjects such as rural-urban migration, urbanisation, and "livelihoods", over and above much of the extensive academic and policy scholarship that exists. This is however very obviously a function of the fact that Mistry's novel is a work of fiction, which meant that he had the freedom to carefully craft his characters in such a way as to reflect the dramatic social reality of impoverishment in India unhindered by the need to respect the inevitably limitations of - always imperfect and partial - empirical research. ${ }^{16}$

A Fine Balance's powerful narrative also allows it to transcend its difficult, even unattractive subject matter and edge towards a universal appeal based on a kind of "humanism with politics". At least partly as a result of this, it has been taken up by a wide audience, selling over half a million copies in the US alone by 2002, a much wider circulation than any academic or policy work on the same subject. ${ }^{17}$ This is clearly another way in which literary fiction can claim to often be "better" than academic or policy texts, as it is clear that they will generally reach far more people and may therefore be more influential than academic or policy works in shaping public knowledge and understanding of development issues, which is of course crucial in terms of building public support for development policies, insofar as this is rarely determined merely by their content. ${ }^{18}$ Sometimes this is clearly the result of a specific conjunction of events. For example, the US invasion of Afghanistan and continuing "war on terror" have obviously played a significant role in the success of Khaled Hosseini's extraordinarily popular novel The Kite Runner (2003), which has arguably done more to educate Western readers about the realities of daily life in Afghanistan (under the Taliban and thereafter) than any government media campaign, advocacy organisation report, or social science research.

The same is also true of another recent Booker Prize-nominated novel, Brick Lane by Monica Ali (2003). This rapidly became a fixture at the top of the UK bestseller lists following its publication, and led to its author joining the ranks of the prestigious "Granta New Young British Novelist" list. The novel chronicles the life of Nazneen, a Bangladeshi woman who is sent to Britain at age 18 to marry Chanu, a man twice her age. It provides a rich narrative of

\footnotetext{
${ }^{16}$ For two examples of academic works that attempt to create a fictionalised "ideal type" of their object of study based on but not limited by the empirical reality of their underlying research, see Taussig (1996) and Hecht (2006), respectively on the nature of the state in Latin America and on the plight of street children in Brazil. Such works are extremely rare within the social sciences, however, and it is interesting to note that both of these originate from anthropology, perhaps the most empirical of social science disciplines.

${ }^{17}$ A Fine Balance was also the winner of the 1996 Commonwealth Writers Prize and was selected by the US television personality Oprah Winfrey as her "book of the month choice", all of which likely also boosted its sales. ${ }_{18}$ Of course, it is important to note that the power of literary fiction as a widespread and significant source of popularised information to shape public opinion can also be appropriated to promote ideas and notion that could be construed as "anti-developmental". The controversy surrounding Michael Crichton's (2004) recent novel State of Fear and its message about the ambiguities of global warming is a case in point (see Crowley, 2006).
} 
the joys and difficulties of her new life, magnificently situating it within wider descriptions of the Bangladeshi migrant community in London that traces its fears, tensions, and aspirations. A particularly important element of the novel is the juxtaposition of Nazneen's life in London with that of her sister, Hasina, who has remained in Bangladesh. Through a series of letters, we see how Hasina's life becomes increasingly difficult after she leaves her violent husband, migrates from her village to Dhaka, falls afoul of prevailing gender norms, and loses her job in a garment factory when she is accused of behaving in a "lewd manner". The novel thus encompasses a wide range of themes centred on development and social change: the experience of migration to the UK, the politics of organising within migrant communities, inter-generational relationships, rural-urban migration, tensions around gender and culture, and the activities of charitable non-governmental organisations among destitute women workers in Dhaka. As the first book to enter in the UK mainstream to feature the broad subject of Bangladesh and Bangladeshi people - which provides a substantial and increasingly visible immigrant community in the UK, and forms the location of one of Britain's largest aid programmes during the past thirty years - it is arguable that Brick Lane has contributed to wider public understandings of development in ways that no academic writing ever has. ${ }^{19}$

There is also another reason why this novel is particularly relevant to our contention about the value of literary sources of knowledge about development. While it is reasonable to suppose that an author's reasons for writing a novel are bound up in a complex bundle of creative, personal and professional motivations, Brick Lane is at least partly inspired by recent academic research on Bangladeshi women. At the end of the book, the first acknowledgement is to the University of Sussex Institute of Development Studies academic Naila Kabeer, "from whose study of Bangladeshi women garment workers in London and Dhaka (The Power to Choose) I drew inspiration" (Ali, 2003: 371). ${ }^{20}$ Kabeer's (2000) book is a study of gender and labour markets within the context of the simultaneous growth of women's employment in the garment sectors of Dhaka and London. The book contrasts employment conditions for women among Bangladeshi communities in the UK, where women work as home-based machinists in an apparent throwback to a nineteenth century form of economic organisation, with those in Bangladesh, where women from the 1980s onwards have increasingly moved out of seclusion into wage employment within modern, large-scale, export-based garment factories. Ali first became aware of The Power to Choose while working at Verso Press, which published the book. ${ }^{21}$ Here then is a novel which builds on academic research to construct a fictional narrative, responding no doubt to the powerful and evocative testimonies provided by the real women who speak through Kabeer's book. The Kabeer/Ali story is an example of an unusual relationship that developed between "fact"

\footnotetext{
${ }^{19}$ In a recent discussion held by the Development Studies Association with senior staff from DFID, it was acknowledged that learning more about, and contributing to the strengthening of, public understanding of development through development education was a key DFID priority for the future.

${ }^{20}$ It is interesting to note that the novel also pokes fun at academic work. At one point, Nazneen's husband Chanu cites the London School of Economics "World Happiness Survey" to support his argument for returning to Bangladesh: "Research led by professors at the London School of Economics into links between personal spending power and perceived quality of life has found out that Bangladeshis are the happiest people in the world. And LSE is a very respectable establishment, comparable to Dhaka University or Open University." (Ali, 2003: 290). A further irony here is that despite this LSE study being cited from time to time in the press and on websites, we are unable to find any conclusive evidence that it ever existed.

${ }^{21}$ Naila Kabeer, personal communication.
} 
and "fiction" within a subject, and we argue that it is a useful one to consider. The purpose of this example is not to suggest that one 'version' of the story of garment workers has more merits than another, but instead to show potential complementarities between two types of narrative, and to illustrate the ways in which the form through which knowledge is presented has important implications for its readership.

\section{Conclusion: development through literature}

Without falling into the trap of intellectual relativism, in which all "stories" are viewed as equal and thus none can claim to be superior, we have contended that relevant fictional forms of representation can be valuably set alongside other forms of knowledge about development such as policy reports or scholarly writing, as valid contributions to our understandings of development. In this way, literary accounts can be seen - alongside other forms - as an important, accessible and useful way of understanding values and ideas in society. Many of the fictional accounts of development-related issues which exist reveal different sides to the experience of development to more formal literature, and may sometimes actually do a "better" job in conveying complex understandings of development in certain respects. While fiction may not always be "reliable" data in the sense of constituting a set of replicable or stable research findings, it may nevertheless be "valid" knowledge in that it may be seen "to reflect an external reality" (Elliot 2005: 22).

At the same time, story-telling as a narrative form and research method has long existed within the social sciences. It can come in the shape of case study material of individual experience or more broadly as ethnographic writing within anthropological texts, for example. While such narrative styles have long formed a part of the inter-disciplinary field of development studies, they have been rarely been part of the mainstream. The same is true at the level of policy, although individual narratives have found their way into policy discourses from time to time, as the "Voices of the Poor" case illustrates, or less recently, in the case of Ken Loach's "Cathy Come Home" television documentary which influenced UK social policy debates about homelessness in the UK. Yet we must distinguish here between "stories" or "narratives" as a representational form of knowledge - a long acknowledged research and presentation method in the social sciences (see Elliot 2005 for a good overview) - and "fiction" as a literary form that we argue can contribute usefully to development knowledge. While the World Bank's "Voices of the Poor" initiative offers stories as illustrations within a meta-narrative, a novel such as A Fine Balance provides a visceral, fine-grained account in which ordinary people are the narrative.

Works of fiction can thus offer a wide-ranging set of insights about development processes that are all too often either ignored or de-personalised within academic or policy accounts, without compromising either complexity, politics or readability in the way that academic literature is often accused of doing. It is clear that literary works sometimes have a stronger Geertzian "being there" quality than certain academic and policy works, they may cover aspects of development that are often not made explicit in conventional academic accounts, 
or else they are written in a more engaging and accessible manner. ${ }^{22}$ Furthermore, partly for this latter reason, works of literary fiction often reach a much larger and diverse audience than academic texts and may therefore be more influential than academic work in shaping public knowledge and understanding of development issues. If more people get their ideas about development from fiction than from academic writing, then surely the fiction of development itself constitutes a potentially important site for the study of development knowledge.

The challenge is therefore to understand better the relationships between different accounts and forms of representation within development writing, as well as noting the multiplicity of voices and logics. In the UK at least, the inter-disciplinary field of development studies has for the past decade and a half been struggling with two persistent dilemmas. The first is the "impasse" in development theory identified by David Booth $(1985,1993,1994)$, while the second is the tension between theory and practice set out most vociferously by Michael Edwards (1989) in his accusation of the "irrelevance of development studies". We would like to add to this list the idea that there is perhaps also a crisis of representation in development research, which is highlighted by the power and success of the fictional accounts of development ideas and processes which we have drawn attention to in this paper. In order to properly understand and communicate notions of development, it is perhaps necessary for us to develop forms of writing that can engage with the economic and political realities and human struggles and challenges of development in ways that go beyond the conventional academic and policy forms of development writing, and much may be learnt in this regard from fictional forms of representation.

Ultimately, as Anthony Giddens (1984: 285) has pointed out, "literary style is not irrelevant to the accuracy of social descriptions", because "the social sciences draw upon the same source of description (mutual knowledge) as novelists or others who write fictional accounts of social life". Indeed, this is something that is being increasing recognised in the opposite direction, with literature studies now beginning to borrow from formal development writing, as illustrated by the literary critic Olakunle George (2000) in a recent essay comparing Mahmood Mamdani's well-known political science monograph Citizen and Subject (1996) with the literary writings of Nobel laureate Wole Soyinka. Taking such efforts as an example, it is clear that a richer and "truer" perspective on the experience of development is most likely to be achieved by holding the insights and imperatives of literature, social science, and policy-making in tension with each other, irrespective of which one is more "truthful". Ultimately, as Mario Vargas Llosa (1996: 320 \& 330) has pointed out, although it may well be that "novels lie", it is also the case that "men do not live by truth alone; they also need lies", ${ }^{23}$ and as such development studies can only benefit from broadening its sources of knowledge to include what we might term "the fiction of development". Indeed, it may even be an essential precondition to reviving the discipline of development studies; as George Eliot observed over 150 years ago:

\footnotetext{
${ }^{22}$ While we are in this paper primarily concerned with fiction in the form of the novel, it could also be claimed that similar objective could be achieved through a greater prominence of ethnographic writing about development $-\mathrm{a}$ topic that would require a separate paper.

${ }^{23}$ We are grateful to James Dunkerley for bringing this citation - and that previously quoted by Sir Thomas More - to our attention in his inaugural lecture for the Institute for the Study of the Americas delivered at the Chancellor's Hall, Senate House, University of London, on 25 October 2004.
} 
Appeals founded on generalisations and statistics require a sympathy readymade, a moral sentiment already in activity; but a picture of human life such as a great artist can give, surprises even the trivial and the selfish into that attention to what is apart from themselves, which may be called the raw material of moral sentiment. ${ }^{24}$

${ }^{24}$ Cited in Gill (1970: 10). 


\section{Recommended reading list of literary fiction on development}

NB/ All books are English-language or translations. Different and other language editions of these works may exist.

- Achebe, C., (1958), Things Fall Apart, London: Heinemann.

- Ali, M., (2003), Brick Lane, London: Doubleday.

- Amado, J., (1965 [1943]), The Violent Land, New York: Knopf.

- Ballard, J. G., (1994), Rushing to Paradise, London: Harper Collins.

- Ballard, J. G., (1987), The Day of Creation, London: Victor Gollancz.

- Borges, J. L., (2000 [1964]), Labyrinths: Selected Short Stories and Other Writings, London: Penguin Books.

- Boyd, W., (1982), A Good Man in Africa, London: Penguin.

- Boyd, W., (1991), Brazzaville Beach, London: Penguin.

- Brunner, J., (1968), Stand on Zanzibar, New York: Ballantine.

- Buck, P. S., (2004 [1931]), The Good Earth, New York: Simon \& Schuster.

- Camus, A., (1994 [1948]), The Plague, New York: First Vintage International.

- Carpentier, A., (1989 [1957]), The Kingdom of This World, New York: Farrar, Straus \& Giroux.

- Cohen, A., (1996 [1968]), Belle du Seigneur: A Novel, New York: Viking.

- Condé, M., (1996 [1984]) Segu, New York: Penguin.

- Conrad, J., (1990 [1902]), Heart of Darkness, New York: Dover Publications.

- Conrad, J. (1983 [1904], Nostromo, London: Penguin.

- Darko, A., (1995), Beyond the Horizon, London: Heinemann.

- de Bernières, L., (1990), The War of Don Emmanuel's Nether Parts, London: Secker \& Warburg.

- Desai, A., (2000), Diamond Dust and Other Stories, London: Chatto \& Windus.

- Farrell, J. G., (1973), The Siege of Krishnapur, London: George Weidenfeld \& Nicholson.

- Fielding, H., (1994), Cause Celeb, London: Picador.

- Forster, E. M., (2000 [1924]), A Passage to India, London: Penguin.

- Frisch, M., (1959 [1957]), Homo Faber, New York: Harcourt.

- Fuentes, C., (1989 [1987]), Christopher Unborn, New York: Farrar, Straus \& Giroux.

- Galgut, D., (2004), The Good Doctor, London: Atlantic Books.

- Garcia Marquez, G., (1997 [1985[), Love in the Time of Cholera, New York: Knopf.

- Garcia Marquez, G., (1995 [1967]), One Hundred Years of Solitude, New York: Knopf.

- Genet, J., (1988 [1958]), The Blacks: A Clown Show, New York: Grove Press.

- Gordimer, N., (1978), The Conservationist, London: Penguin.

- Green, G., (1991 [1955]), The Quiet American, London: Penguin.

- Kadaré, I., (2005 [1981]), The Palace of Dreams, London: Harvill Press.

- Kingsolver, B., (1998), The Poisonwood Bible, New York: Harper Collins.

- Kipling, R., (1987 [1901]), Kim, London: Penguin.

- Kourouma, A., (1997 [1970]), The Suns of Independence, Teaneck: Holmes \& Meier Publishers. 
- Kourouma, A., (2001 [1998]), Waiting for the Vote of the Wild Animals, Charlottesville: University of Virginia Press.

- Kourouma, A., (2005 [2000]), Allah is not obliged, London: Heinemann.

- Lahiri, J., (1999), Interpreter of Maladies, New York: Houghton Mifflin.

- Lapierre, D., (1985), The City of Joy, New York: Warner Books.

- Le Carré, J., (2000), The Constant Gardener, New York: Scribner.

- Maalouf, A., ([1983]), The Crusades Through Arab Eyes, London: Saqi Books.

- Mahfouz, N., (1993 [1966]), Adrift on the Nile, New York: Anchor Books.

- Mahjoub, J., (1989), Navigation of a Rainmaker, London: Heinemann.

- Mahjoub, J., (1994), Wings of Dust, London: Heinemann.

- Mistry, R., (1996), A Fine Balance, London: Faber and Faber.

- Molteno, M., (1992), A Shield of Coolest Air, London: Shola Books.

- Mwangi, M., (1976), Going Down River Road, London: Heinemann.

- Naipaul, V. S., (2001 [1961]), A House for Mr. Biswas, New York: First Vintage International.

- Narayan, R. K., (1993 [1976]), The Painter of Signs, London: Penguin.

- Neruda, P., (2003 [1947]), Residence on Earth, London: Souvenir Press.

- Neruda, P., (1993 [1950]), Canto General, Berkeley: University of California Press.

- Okri, B., ([1991]), The Famished Road, New York: Anchor Books

- Ondaatje, M., (2000), Anil's Ghost, London: Bloomsbury.

- Ousmane, S., (1972), The Money Order, London: Heinemann.

- Rush, N., (1992), Mating, New York: Vintage.

- Rushdie, S., (1981), Midnight's Children, London: Picador.

- Saith, V., (1993), A Suitable Boy, London: Phoenix.

- Sepulveda, L., (1993 [1989]), The Old Man who read Love Stories, New York: Harcourt.

- Shukla, S., (1992 [1968]), Raag Darbari, New Delhi: Penguin India.

- Soueif, A., (1999), The Map of Love, London: Bloomsbury.

- Soyinka, W., (1963), A Dance of the Forests, Oxford: Oxford University Press.

- Tweedie, J., (1987), Internal Affairs, London: Penguin.

- Vargas Llosa, M., (1975 [1969]), Conversations in the Cathedral, New York: Harper \& Row.

- Walcott, D., (1990), Omeros, New York: Farrar, Straus \& Giroux.

- wa Thiong'o, Ngugi, (1977), Petals of Blood, London: Penguin.

- wa Thiong'o, Ngugi, (1989), Matigari, London: Heinemann.

- Xingjian, G., (2000 [1990]), Soul Mountain, New York: Harper Collins. 


\section{References}

Achebe, C., (1958), Things Fall Apart, London: Heinemann.

Ahmad, A., (1987), "Jameson's Rhetoric of Otherness and the 'National Allegory'”, Social Text, 17: 3-25.

Ali, M., (2003), Brick Lane, London: Doubleday.

Ballard, J. G., (1987), The Day of Creation, London: Victor Gollancz.

Bebbington, A., M. Woolcock, S. Guggenheim, and E. Olson, (2004), "Exploring Social Capital Debates at the World Bank", Journal of Development Studies, 40(5): 33-64.

Benjamin, W., (1989), "On the Program of the Coming Philosophy", translated by M. Ritter, in G. Smith (ed), Benjamin: Philosophy, Aesthetics, History, Chicago: University of Chicago Press.

Benjamin, W., (1999), The Arcades Project, translated by H. Eiland and K. McLaughlin, Cambridge: The Belknap Press of Harvard University Press.

Booth, D., (1985), "Marxism and Development Sociology: Interpreting the Impasse", World Development, 13(7): 761-787.

Booth, D., (1993), "Development Research: From Impasse to a New Agenda", in F. J. Schuurman (ed), Beyond the Impasse: New Directions in Development Theory, London: Zed Books.

Booth, D., (1994), "How Far beyond the Impasse: A Provisional Summing Up", in D. Booth (ed), Rethinking Social Development: Theory, Research and Practice, London: Longman Publishing Group.

Byron, G. G. N. (Lord), (1973 [1819-24]), Don Juan, edited by T. G. Steffan, E. Steffan, and W. W. Pratt, London: Penguin.

Collier, P., and J. W. Gunning, (1999), "Explaining African Economic Performance", Journal of Economic Literature, 37(March): 64-111.

Conrad, J., (1985 [1897]), The Nigger of the 'Narcissus': A Tale of the Sea, edited and with an introduction by J. Berthoud, Oxford: Oxford University Press.

Coser, L., (1972[1963]), Sociology through Literature, Englewood Cliffs, NJ: Prentice Hall.

Crichton, M. (2004), State of Fear, New York: Avon Books.

Crowley, M., (2006), "Jurassic President”, The New Republic, March 20.

Czarniawska-Joerges, B., (1992), Exploring Complex Organizations: A Cultural Perspective, Newbury Park: Sage Publications.

Denning, S., (2000), The Springboard: How Storytelling Ignites Action in Knowledge-Era Organizations, Woburn: Butterworth-Heinemann.

Edwards, M., (1989), "The Irrelevance of Development Studies", Third World Quarterly, 11(1): 116-135.

Elliot, J., (2005), Using Narrative in Social Research: Qualitative and Quantitative Approaches. London: Sage.

Emecheta, B., (1976), The Bride Price, London: Allison \& Busby.

Escobar, A., (1995), Encountering Development: The Making and Unmaking of the Third World, Princeton: Princeton University Press.

Ferguson, J., (1990), The Anti-Politics Machine: Development, Depoliticization and Bureaucratic Power in Lesotho, Minneapolis: University of Minnesota Press.

Fielding, H., (1994), Cause Celeb, London: Picador. 
Foucault, M., (1984), "What Is an Author?" in P. Rabinow (ed), The Foucault Reader, New York: Pantheon.

Geertz, C. (1988) Works and Lives: The Anthropologist as Author. Stanford CA: Stanford University Press.

George, O., (2000), "African Politics, African Literatures: Thoughts on Mahmood Mamdani's Citizen and Subject and Wole Soyinka's The Open Sore of a Continent", West Africa Review, 2(1): 1-13.

Giddens, A., (1984), The Constitution of Society: Outline of the Theory of Structuration, Berkeley: University of California Press.

Gill, S., (1970), "Introduction", in E. Gaskell, Mary Barton: A Tale of Manchester Life, London: Penguin.

Godwin, W., (1993 [1793]), Enquiry Concerning Political Justice and Its Influence on Modern Morals and Happiness, edited by I. Kramnick, Harmondsworth: Penguin.

Gupta, A., (2005), "Narratives of Corruption: Anthropological and Fictional Accounts of the Indian State", Ethnography, 6(1): 5-34.

Hecht, T., (2006), After Life: An Ethnographic Novel, Durham: Duke University Press.

Herman, D., (2001) Poverty of the Imagination: Nineteenth-Century Russian Literature about the Poor, Evanston, IL: Northwestern University Press.

Hilhorst, D., (2003), The Real World of NGOs: Discourses, Diversity and Development, London: Zed Books.

Horace, (1959), "The Art of Poetry", in Satires and Epistles of Horace, edited and translated by Smith Palmer Bovie, Chicago: Chicago University Press.

Hosseini, K., (2003), The Kite Runner, New York: Riverhead Books.

Jameson, F., (1986), "Third-World Literature in the Era of Multinational Capitalism", Social Text, 15: 65-88

Kabeer, N., (2000), The Power To Choose: Bangladeshi Women and Labor Market Decisions in London and Dhaka, London: Verso.

Keen, P., (1999), The Crisis of Literature in the 1790s: Print Culture and the Public Sphere, Cambridge: Cambridge University Press.

Mahfouz, N., (1993 [1966]), Adrift on the Nile, translated by F. Liardet, New York: Anchor Books.

Mahfouz, N., (1993 [1983]), The Journey of Ibn Fattouma, translated by D. Johnson-Davies, New York: Anchor Books.

Mamdani, M., (1996), Citizen and Subject: Contemporary Africa and the Legacy of Late Colonialism, Princeton: Princeton University Press.

Mistry, R., (1996), A Fine Balance, London: Faber and Faber.

Mitchell, T., (1991), Colonising Egypt, Berkeley: University of California Press.

Mitchell, T., (ed.), (2000), Questions of Modernity, Minneapolis: University of Minnesota Press.

Mitchell, T., (2002), Rule of Experts: Egypt, Techno-Politics, Modernity, Berkeley: University of California Press.

Moore, M., (1987), "What Sort of Ideas Become Public Ideas?", in R. Reich (ed), The Power of Public Ideas, New York: Harper Business.

More, T. (Sir), (1964), "Letter to Peter Giles", in E. Surtz and J.H. Hexter (eds.), The Complete Works of Sir Thomas More, vol. 4, New Haven: Yale University Press. 
Mosse, D., (2004), Cultivating Development: An Ethnography of Aid Policy and Practice, London: Pluto Press.

Narayan, D., with R. Patel, K. Schafft, A. Rademacher, and S. Koch-Schulte, (2000a), Voices of the Poor: Can Anyone Hear Us?, New York: Oxford University Press.

Narayan, D., R. Chambers, M. Kaul Shah, and P. Petesch, (2000b), Voices of the Poor: Crying Out for Change, New York: Oxford University Press.

Narayan, D., and P. Petesch, (2002), Voices of the Poor: From Many Lands, New York: Oxford University Press.

Pritchett, L., and M. Woolcock, (2004), "Solutions When the Solution is the Problem: Arraying the Disarray in Development", World Development, 32(2): 191-212.

Roe, E. M., (1991), "Development Narratives, or Making the Best of Blueprint Development", World Development, 19(4): 287-300.

Roe, E. M., (1994), Narrative Policy Analysis, Durham: Duke University Press.

Said, E.W., (1993), Culture and Imperialism, London: Chatto \& Windus.

Schech, S. and J. Haggis, (2000), Culture and Development: A Critical Introduction, Oxford: Blackwell.

Scott, J., (1998), Seeing Like a State: How Well-Intentioned Efforts to Improve the Human Condition Have Failed. New Haven: Yale University Press.

Sherman, S., (2001), Imaging Poverty: Quantification and the Decline of Paternalism, Columbus: Ohio State University Press.

Shukla, S., (1992 [1968]), Raag Darbari, translated by G. Wright, New Delhi: Penguin India.

Sidney, P. (Sir), (2002 [1595]), An Apology for Poetry (or The Defence of Poesy), edited by G. Shepherd and R. W. Maslen, Manchester: Manchester University Press.

Soueif, A., (1999), The Map of Love, London: Bloomsbury.

Soyinka, W., (1996), The Open Sore of a Continent: A Personal Narrative of the Nigerian Crisis, Oxford: Oxford University Press.

Szeman, I., (2001), "Who's Afraid of National Allegory? Jameson, Literary Criticism, Globalization", South Atlantic Quarterly, 100(3): 803-27.

Taussig, M., (1996), The Magic of the State, New York: Routledge.

Vargas Llosa, M., (1996), "The Truth of Lies", in Making Waves: Essays, translated by John King, London: Faber and Faber.

Von Struensee, V., (2004), "The Domestic Relations Bill in Uganda: Addressing Polygamy, Bride Price, Cohabitation, Marital Rape, and Female Genital Mutilation", paper downloaded from the Social Science Research Network (SSRN), http://ssrn.com/abstract $=623501$.

White, H., (1973), Metahistory: The Historical Imagination in Nineteenth Century Europe, Baltimore and London: John Hopkins University Press.

World Bank, (2000), Can Africa Claim the $21^{\text {st }}$ Century?, Washington, DC: The World Bank. 
Executive Director

Professor Tony Addison

Research Director

Professor Michael Woolcock

Associate Director

Professor David Hulme

\section{Contact:}

Brooks World Poverty Institute

The University of Manchester

Humanities Bridgeford Street

Building

Oxford Road

Manchester

M13 9PL

United Kingdom

Email: bwpi@manchester.ac.uk

www.manchester.ac.uk/bwpi
The Brooks World Poverty Institute (BWPI) creates and shares knowledge to help end global poverty.

BWPI is multidisciplinary, researching poverty in both the rich and poor worlds.

Our aim is to better understand why people are poor, what keeps them trapped in poverty and how they can be helped - drawing upon the very best international practice in research and policy making.

The Brooks World Poverty Institute is chaired by Nobel Laureate, Professor Joseph E. Stiglitz. 